\title{
ADATOK A VALLÁSOSSÁG PROTEKTÍV SZEREPÉHEZ A TESTI ÉS LELKI EGÉSZSÉGBEN
}

\author{
ZONDA TAMÁS ${ }^{1 *}$ - PAKSI BORBÁLA² \\ ${ }^{1}$ Magyar Szuicidium-Prevenciós Társaság, Budapest \\ ${ }^{2}$ Budapesti Corvinus Egyetem, Viselkedéskutató Központ, Budapest
}

(Beérkezett: 2005. október 9.; elfogadva: 2006. január 10.)

\begin{abstract}
A szerzók egy-egy, hagyományosan magas és alacsony öngyilkossági rátájú megye reprezentatív mintáján végeztek komplex felmérést, mely során néhány, a vallásossággal kapcsolatos kérdést is feltettek. A felmérés anyagából kigyưjitve megvizsgálták a külsó és belső vallásosság és az egészségmagatartás közötti összefüggést. A mintában a vallásos személyek között jóval intenzívebbnek bizonyult az élet értéke és az annak megốrzésére való törekvés: szignifikánsan alacsonyabb az alkoholt fogyasztók és a dohányosok száma, többen utasítják el az öngyilkosságot, kevesebben foglalkoztak ennek gondolatával és sokkal gyakrabban, többen járnak el rákszúrésre, pszichológushoz. A depresszív megbetegedés és az öngyilkossági kísérletek terén szignifikáns különbség nem jelentkezett. Az alacsony öngyilkossági rátájú megyében közel kétszer annyi a katolikus vallású, szignifikánsan intenzívebb a vallásgyakorlás, a hit szerepe a mindennapokban. A talált adatokat figyelembe kellene venni a szomatikus és mentális betegségek megelőzésében egyaránt.
\end{abstract}

Kulcsszavak: vallásosság, egészségmagatartás, öngyilkosság, major depresszió

\section{BEVEZETÉS}

A mély hit, az igazán átélt vallásosság hatalmas erót, tartalékot biztosít egyednek, közösségnek, nemcsak a mindennapok elviselésében és a végsố kérdések megválaszolásában, hanem jótékonyan hat a lelki, de még a testi egészségre is. E kijelentés azonban számos buktatót is hordoz, hi-

* Levelezô szerzô: Dr. Zonda Tamás, 1121 Budapest, Mártonhegyi út 22/d.

E-mail: zondat@freemail.hu 
szen maga a vallásosság, de még a vallás fogalma sem egyértelmúen definiálható. Utóbbinak két legpolarizáltabb megfogalmazása: „Az értelmes teremtmény viszonya az istenséghez, mint elsódleges elvhez és végsó célhoz" (Aquinói Szent Tamás), illetve "A vallás az emberi lényeg fantasztikus megvalósulása, mert az emberi lényegnek nincs igazi valósága" (Marx).

Ha el is fogadunk a vallásosságot illetően egy, a józan ész és a mindennapi gyakorlat által jól körülhatárolt, egyértelmú magatartást, bizonyítható meggyőződést, az ennek talaján keletkezett felmérések számos értelmezési, metodikai problémát rejthetnek, amint azt egy, az irodalmat összegezó tanulmány is jelzi (Farkas és mtsai 2005). Mindazonáltal nagyszámú vizsgálat igazolta a vallásosság, a mély hit egészségvédó szerepét (Culliford 2002; Fabrega 2002; Koenig és mtsai 2001). Towsend és munkatársai (2003) metaanalízise szerint a vallásos hit kedvezóen hat a vérnyomásra, az immunrendszerre, a depresszióra és a halálozási mutatókra. Egy 1972-es kutatás szerint - amelyben közel 92000 személyt vizsgáltak Észak-Amerikában - a heti rendszerességgel templomba járók körében szignifikánsan alacsonyabb volt a szívkoszorúér-betegség, a májzsugorodás és az öngyilkosság (cit. Cseri 2004). A szomatikus betegségekre történó pozitív hatást mutató kutatások felsorolása nagyszámú, bár az egyértelmúen jótékony hatást még több szerző kétségbe vonja, illetve további, jobb metodikai módszerektól vár meggyózóbb bizonyítást (Sloan és mtsai 1999; Powel és mtsai 2003).

A mentális betegségek esetében azonban a hit, a vallásosság segítô és preventív hatásáról alig van vita, az összefüggés már-már evidenciának tekinthetố (Pargament 1997). Idôs depressziós betegeknél vizsgálták precíz módszerekkel a depresszió gyógyulásának fokát, mértékét és időtartamát: a vallásos emberek sokkal gyorsabban gyógyultak meg betegségükból (Koenig és mtsai 1998). Egy nagy finnországi vizsgálat szerint a vallásos embernek sokkal betegebbnek kell lennie mentálisan ahhoz, hogy eljusson az öngyilkosság elkövetéséig, mint a nem hívőnek (Sorri és mtsai 1996). Angliában ötszáz diáknál azt találták, hogy a gyakran imádkozók körében lényegesen alacsonyabb volt a szorongás, a depresszió és erósebb az önértékelés (Maltby és mtsai 1999). A vallás és egészség kapcsolatával foglalkozó 1200 tanulmány és 400 kutatási beszámoló metaanalízise az mutatta, hogy a vallásos népesség körében több a remény jövójüket illetôen, jobb a pszichés-spirituális jóllét, nagyobb az önbecsülés, jobb a gyászhoz való alkalmazkodás, erósebb a társas támogatórendszer, kevesebb a magányosság, a depresszió, a szorongás, az alkoholizmus, az öngyilkosság, a bủncselekmény, és stabilabbak a házasságok (Koenig és mtsai 2001).

A vallási és spirituális dimenziók tehát fontos kulturális faktorai az em- 
beri létezésnek, viselkedésnek, de a betegségi patterneknek is, ezért a WHO legutóbbi anyagaiban már az ember bio-pszicho-szociális meghatározottsága mellé felvette a spirituális dimenziót is (Manson 1996).

Magyarországon a vallás protektív szerepe a szomatikus és pszichés betegségekben meglehetôsen alulkutatott terület. Hosszú időn keresztül a politikai berendezkedés nem csak a vallási, egyházi életet, a hitgyakorlatot, de az ezt feltérképezni igyekvő adatgyújtést, tudományos vizsgálódást is akadályozta. A felekezeti hovatartozás népszámlálási felmérése - nagy vitákat követően - 1949 után csak 2002-ben vált lehetóvé.

A magyar lakosság mentális egészségét, egészségmagatartását nagyobb mintán vizsgáló, reprezentatív felmérés 1988-ban, 1995-ben és 2002-ben történt (Kopp és Skrabski 1995, 2000; Kopp és mtsai 2004). Az 1988-as felmérésnél - a jelzett okokból - még nem volt mód a vallással kapcsolatos kérdések feltevésére. Az 1995. és a 2002. évi Hungarostudy eredményei azonban egyértelmúen a vallás protektív szerepét jelezték számos egészségügyi vonatkozásban. Az intenzív vallásgyakorlók az országos átlaghoz képest 43\%-kal kevesebb cigarettát szívnak el naponta, 42\%-kal kevesebb napig voltak betegek a vizsgálat elótti évben, munkaképességük jelentôsen jobb volt. Szignifikánsan magasabb pontszámot értek el a WHO jóllét kérdőívén, kevésbé depressziósak, kevésbé ellenségesek, hatékonyabb problémamegoldó képességgel rendelkeznek, és gazdagabb társas támogatásról számoltak be.

\section{MÓDSZER}

Jelen tanulmányunkban ismertetett kutatásunk fố célja a hazai öngyilkosságok területi különbségeinek kulturális-normatív beágyazottsági vizsgálata volt. Ennek során két, pregnánsan eltérô szuicid veszélyeztetettségú, azaz az öngyilkossági hajlandóság szempontjából poláris helyzetú régió összehasonlító felmérését végeztük el. A megyei aggregáltságú öngyilkossági ráták alapján Bács-Kiskun és Vas megye szolgáltak a kutatás terepéül. Bács-Kiskun megye nem csak az öngyilkosságok terén, hanem számos más mutatóban is rosszabb helyzetet mutatott a vizsgálatot megelőzó években, mint Vas megye (1. táblázat).

A táblázat mutatja, hogy olyan (látszólag) eltéró mutatókban jelentkeznek igen markáns különbségek a két megye lakossága körében, melyek erós valószínúséggel okai és/vagy következményei egy nehezen megfogalmazható és definiálható társadalmi diszfunkciónak, mely az alföldi népesség körében lényegesen kifejezettebb. Alapos a feltételezés, hogy a különbségnek mély társadalmi-kulturális gyökerei vannak, azaz az 
1. táblázat. Bács-Kiskun és Vas megye halálozási adatai a különböző, fóbb betegségcsoportokban és balesetekben, 1995-1999 (a szignifikáns eltérést jelzô mutatók dólt betús kiemelésével)

\begin{tabular}{lcc}
\hline Halálokok/100 000 lakos & Bács-Kiskun & Vas \\
\hline Összes halálozás & 1493,0 & 1447,9 \\
Öngyilkosság & 46,4 & 21,4 \\
Daganatos & 301,7 & 325,9 \\
Keringési rendszer & 790,7 & 755,2 \\
Légzốszervi & 84,2 & 83,4 \\
Emésztő́rendszer & 110,3 & 96,9 \\
Alkoholos májbetegség & 0,75 & 0,47 \\
Baleseti halálozás (összes) & 81,6 & 22,6 \\
Közlekedési baleset & 26,6 & 14,6 \\
Egyéb baleset & 55 & 8 \\
\hline
\end{tabular}

észlelt eltérések elsôsorban kulturálisan beágyazottak (Andorka és mtsai 1968).

A vizsgálat a 18 és 70 év közötti lakosság kor, nem és a lakóhely jellege szerint reprezentatív, megyénként 1000-1000 fós mintáján készült. A mintanagyság a standard hibát $95 \%$-os valószínúséggel $\pm 3,2 \%$-ban maximálja. Az adatfelvétel 2000 júliusában történt.

A vizsgálat az alábbi fóbb témaköröket tartalmazta:

- Szocio-ökonómiai státus, demográfiai háttérváltozók: kor, nem, lakáskörülmények, foglalkozás, családösszetétel stb.

- A kérdezett környezetében elóforduló devianciák (differenciális asszociáció elméletek, kulturális tanulás elméletek).

- Az öngyilkosság társadalmi megítélése, minősítése, öngyilkossággal kapcsolatos attitúdök (társadalmi kontroll elméletek).

- A kérdezett személy devianciái (a különféle deviáns magatartások kapcsolata).

- A major depresszió DSM-IV szerinti kategóriái: idópont és életút prevalencia.

- Egészségi állapottal, illetve az egészmagatartással kapcsolatos kérdések.

- Alapérték-teszt és anómia skála (anómia-, illetve integrációs elméletek).

- Külső (formális) és belső vallásosság.

- Néhány, a magyarsághoz kötődést vizsgáló kérdés.

A fenti kérdéskörök közül jelen tanulmányunkban egyrészt a vallásosság és az egészségmagatartás bizonyos indikátorai közötti viszonyt vizsgáljuk ré- 
gió-független egyéni szintú elemzések révén. Másrészt összehasonlitó vizsgálat alá vesszük a két megye vallásosságát, az öngyilkossági arány és más, egészségmagatartással kapcsolatos mutatók mentén markánsan eltérố régiók vallási életében fellelhetô eltéréseket keresve.

A külső (formális) vallásosság fokára a "Megitélése szerint mennyire vallásos?" és a "Hányszor jár misére, istentiszteletre?" kérdésekre adott válaszokból következtetünk. A belső vallásosság indikátoraiként pedig a következô kérdéseket alkalmaztuk: „Vallásos hitem nagymértékben befolyásolja mindennapi életemet", illetve "Vallásos hitem nagymértékben befolyásolja, hogy miképpen hozok meg fontos döntéseket".

A két-két kérdésre csaknem azonos válaszokat kaptunk, így azokat összevontan vizsgáltuk. A kérdésekre (a „Hányszor jár misére, istentiszteletre" kérdés kivételével) hétfokozatú skálán lehetett válaszolni, ahol a két szélsố válasz a „nem”, és a "teljes mértékben” volt. A régió-független elemzések során - a válaszok egymáshoz viszonyított eloszlása alapján - az 1-es és a 2-es válaszokat ateizmusnak, a 6-os és 7-es válaszokat pedig az egyértelmú vallásosságnak feleltettük meg, és összevontuk. A 3-4-5 válaszokat bizonytalan, nehezen definiálható voltuk miatt kihagytuk az elemzésekból, azaz a 7 fokozatú skálák dichotómmá transzformált, ateista és nagyon vallásos kategóriákat elkülönító változatát alkalmaztuk. (A megyei szintú összehasonlító elemzéseknél használtuk a 7 fokozatú skálát, ahol a vizsgálat komparatív jellege miatt torzítás nem jelentkezhetett.)

Az elemzéseket az SPSS 9.0 for Windows programcsomaggal végeztük. (Az egyes személyszámok mellé csak egy tizedesig írtuk ki a program által megadott százalékértékeket, ezért a kummulatív százalékok a 100\%-hoz képest tizedszázaléknyi eltérést mutathatnak.) Asszociációs mérôszámként a Pearson khi-négyzet próbát használtuk. A major depresszió diagnózisához a DSM-IV kategorizációt használtuk.

\section{EREDMÉNYEK}

\section{A vallás és az egészségmagatartás összefüggésének egyéni szintú vizsgálata}

A durkheimi értelemben vett formális (külsô) vallásosság (Durkheim 1982) vizsgálatakor az egyéni szintú elemzések során az alábbiakat találtuk (2. táblázat):

1. A vallásos népesség körében a dohányozás és az alkoholfogyasztás rövid és hosszú távú prevalencia értékei egyaránt szignifikánsan kedvezóbbek. 
2. táblázat. A formális kritériumok alapján „nem vallásos” és „mélyen vallásos” népesség összehasonlítása az egészségmagatartás különböző aspektusai mentén

\begin{tabular}{|c|c|c|c|}
\hline & Ateista & $\begin{array}{l}\text { Nagyon } \\
\text { vallásos }\end{array}$ & Szignifikancia \\
\hline Rendszeresen dohányzik & $\begin{array}{c}210 \\
43,8 \% \\
\end{array}$ & $\begin{array}{c}77 \\
26,7 \%\end{array}$ & 0,001 \\
\hline Életében rendszeresen, sokat ivott & $\begin{array}{c}58 \\
12,1 \%\end{array}$ & $\begin{array}{c}17 \\
5,9 \%\end{array}$ & 0,005 \\
\hline $\begin{array}{l}\text { Élete során foglalkozott az öngyilkosság } \\
\text { gondolatával }\end{array}$ & $\begin{array}{c}25 \\
5,3 \% \\
\end{array}$ & $\begin{array}{c}8 \\
2,8 \% \\
\end{array}$ & 0,072 \\
\hline Élete során volt öngyilkossági kísérlete & $\begin{array}{c}6 \\
1,3 \%\end{array}$ & $\begin{array}{c}2 \\
0,7 \%\end{array}$ & NS* \\
\hline $\begin{array}{l}\text { Van olyan baj, mely esetén elfogadható } \\
\text { az öngyilkosság }\end{array}$ & $\begin{array}{c}155 \\
32,5 \%\end{array}$ & $\begin{array}{c}62 \\
21,5 \%\end{array}$ & 0,005 \\
\hline $\begin{array}{l}\text { Élete során volt major depressziója } \\
\text { (lifetime) }\end{array}$ & $\begin{array}{c}47 \\
9,8 \%\end{array}$ & $\begin{array}{c}28 \\
9,7 \%\end{array}$ & NS* \\
\hline $\begin{array}{l}\text { Egészségi állapota kifejezetten jó } \\
\text { vagy inkább jó }\end{array}$ & $\begin{array}{c}388 \\
81,2 \%\end{array}$ & $\begin{array}{c}217 \\
75,4 \%\end{array}$ & NS* \\
\hline $\begin{array}{l}\text { Másokhoz képest egészségesebbnek } \\
\text { érzi magát }\end{array}$ & $\begin{array}{c}97 \\
20,3 \%\end{array}$ & $\begin{array}{c}59 \\
21,5 \%\end{array}$ & NS* \\
\hline $\begin{array}{l}\text { Élete során járt pszichológushoz, } \\
\text { idegorvoshoz }\end{array}$ & $\begin{array}{c}21 \\
4,4 \% \\
\end{array}$ & $\begin{array}{c}21 \\
7,3 \%\end{array}$ & NS* \\
\hline $\begin{array}{l}\text { Élete során rendszeresen szedett altatót } \\
\text { vagy nyugtatót }\end{array}$ & $\begin{array}{c}39 \\
8,2 \%\end{array}$ & $\begin{array}{c}38 \\
13,3 \% \\
\end{array}$ & 0,026 \\
\hline Rendszeresen jár rákszúrésre & $\begin{array}{c}91 \\
19,0 \%\end{array}$ & $\begin{array}{c}79 \\
27,5 \%\end{array}$ & 0,006 \\
\hline Rendszeresen jár tüdőszúrésre & $\begin{array}{c}363 \\
91,9 \%\end{array}$ & $\begin{array}{c}227 \\
94,2 \%\end{array}$ & NS* \\
\hline
\end{tabular}

*NS: nem szignifikáns

2. A vallásosak körében tendenciájában kevesebben foglalkoztak életük folyamán az öngyilkosság gondolatával, és szignifikánsan többen vannak közülük, akik nem tudják elfogadni az öngyilkosságot, mint megoldást egy gond, baj, probléma, krízis stb. esetén.

3. Az egészségtudatos magatartás indikátoraként alkalmazott szúréslátogatásokkal kapcsolatos kérdések közül a rákszúrés tekintetében mutatkozott szignifikánsan a várt összefüggés: a vallásos csoport tagjai nagyobb arányban járnak rákszúrésre, mint a vallástalan csoportba tartozók.

4. Az ateista megkérdezettek körében háromszor annyi öngyilkossági kísérlet történt, mint a vallásos megkérdezettek körében, mindazonáltal a különbség - az alacsony esetszám következtében - nem szignifikáns, 
így nem értelmezhetô az ateista és a vallásos népességre jellemző különbségként.

5. A „Milyennek ítéli meg egészségi állapotát?”, illetve a „Másokhoz képest egészségesebbnek érzem magam" kérdésekre adott válaszokban jelentkezó eltérések egyrészt ellentétes irányúak, másrészt nem szignifikánsak.

6. Csaknem azonos arányban fordult eló major depresszió az élet folyamán (lifetime) a két csoportban, tehát a formális vallásosság nem bizonyult védó hatásúnak a depresszív állapotokra nézve.

7. A vallásos válaszolók életük során jóval nagyobb arányban jártak pszichológushoz, mint az ateisták, a különbség azonban nem szignifikáns.

8. A vallásosak szignifikánsan nagyobb hányada szedett élete során nyugtatót vagy altatót.

A belsô vallásosság szerepét a fentivel azonos változókra nézve vizsgáltuk (3. táblázat). Az alábbiakban csak a formális indikátorok mentén bemutatott összefüggésektól eltérô kapcsolatokat emeljük ki:

1. Az „Élete folyamán foglalkozott-e az öngyilkosság gondolatával” kérdésre adott válaszok tekintetében a külsô vallásosság vizsgálatakor tendencia jelleggel megfigyelhetô különbség a belső vallásosság összefüggésében a két népesség között nem jelentkezett.

2. Másokhoz viszonyítva a mélyen vallásosak szignifikánsan egészségesebbnek tartják magukat. Ugyanakkor a „Milyennek ítéli meg egészségi állapotát?" kérdés vonatkozásában a belsố vallásosság esetében a várakozásokkal ellentétes tendencia jellegú különbség mutatkozott: az ateista népesség érzi magát egészségesebbnek.

3. A mélyen vallásosak csoportja szignifikánsan gyakrabban járt pszichológushoz, idegorvoshoz élete során.

Vizsgálatunk során tehát a külsố és belsố vallásosság között az egészségügyi magatartást és a mentálhigiénés állapotokat illetóen érdemi különbséget nem találtunk.

A vallásosak és ateisták között azonban néhány egészségmagatartási dimenzióban igen egyértelmú különbség jelentkezett. A vallásos népesség körében a dohányzás és az alkoholfogyasztás rövid és hosszú távú prevalencia értékei egyaránt szignifikánsan kedvezóbbek, közülük jóval nagyobb számban utasítják el az öngyilkosságot, mint egy probléma megoldását; inkább jártak pszichológushoz, idegorvoshoz, és sokkal nagyobb arányba járnak (jártak) rákszúrésre. Mindezt magunk úgy látjuk interpretálhatónak, hogy a vallásos csoport sokkal többet törődik egészségével, ami a saját élet értékének, fontosságának hangsúlyát jelzi. Ugyanakkor a depresszív megbetegedés, illetve az öngyilkossági kísérletek gyakorisága terén érdemi védófunkciót kimutatni nem tudtunk a vallásosak javára. 
3. táblázat. A belső vallásosság két szélsőségét képviselő népesség összehasonlítása a jelzett változók mentén

\begin{tabular}{|c|c|c|c|}
\hline & Ateista & $\begin{array}{l}\text { Nagyon } \\
\text { vallásos }\end{array}$ & Szignifikancia \\
\hline Rendszeresen, dohányzik & $\begin{array}{c}465 \\
39,9 \%\end{array}$ & $\begin{array}{c}34 \\
18,7 \%\end{array}$ & 0,001 \\
\hline Életében rendszeresen, sokat ivott & $\begin{array}{c}114 \\
9,8 \%\end{array}$ & $\begin{array}{c}10 \\
5,5 \% \\
\end{array}$ & 0,038 \\
\hline $\begin{array}{l}\text { Élete során foglalkozott az öngyilkosság } \\
\text { gondolatával }\end{array}$ & $\begin{array}{c}53 \\
4,5 \%\end{array}$ & $\begin{array}{c}7 \\
3,9 \% \\
\end{array}$ & NS* \\
\hline Élete során volt öngyilkossági kísérlete & $\begin{array}{c}18 \\
1,5 \%\end{array}$ & $\begin{array}{c}2 \\
0,6 \%\end{array}$ & NS* \\
\hline $\begin{array}{l}\text { Van olyan baj, mely esetén elfogadható } \\
\text { az öngyilkosság }\end{array}$ & $\begin{array}{c}344 \\
29,5 \% \\
\end{array}$ & $\begin{array}{c}41 \\
22,5 \% \\
\end{array}$ & 0,004 \\
\hline $\begin{array}{l}\text { Élete során volt major depressziója } \\
\text { (lifetime) }\end{array}$ & $\begin{array}{c}115 \\
9,9 \% \\
\end{array}$ & $\begin{array}{c}16 \\
8,8 \% \\
\end{array}$ & NS* \\
\hline $\begin{array}{l}\text { Egészségi állapota kifejezetten jó } \\
\text { vagy inkább jó }\end{array}$ & $\begin{array}{c}942 \\
80,8 \% \\
\end{array}$ & $\begin{array}{c}137 \\
74,2 \% \\
\end{array}$ & 0,072 \\
\hline $\begin{array}{l}\text { Másokhoz képest egészségesebbnek } \\
\text { érzi magát }\end{array}$ & $\begin{array}{c}245 \\
21,0 \%\end{array}$ & $\begin{array}{c}41 \\
22,5 \% \\
\end{array}$ & 0,013 \\
\hline $\begin{array}{l}\text { Élete során járt pszichológushoz, } \\
\text { idegorvoshoz }\end{array}$ & $\begin{array}{c}63 \\
5,4 \% \\
\end{array}$ & $\begin{array}{c}14 \\
7,7 \% \\
\end{array}$ & 0,025 \\
\hline $\begin{array}{l}\text { Élete során rendszeresen szedett } \\
\text { altatót vagy nyugtatót }\end{array}$ & $\begin{array}{c}101 \\
8,7 \% \\
\end{array}$ & $\begin{array}{c}25 \\
13,8 \% \\
\end{array}$ & 0,031 \\
\hline Rendszeresen jár rákszưrésre & $\begin{array}{c}502 \\
43,1 \% \\
\end{array}$ & $\begin{array}{c}115 \\
62,6 \% \\
\end{array}$ & 0,001 \\
\hline Rendszeresen jár tüdôszûrésre & $\begin{array}{c}1098 \\
94,2 \%\end{array}$ & $\begin{array}{c}174 \\
94,5 \%\end{array}$ & NS* \\
\hline
\end{tabular}

NS*: nem szignifikáns

\section{A vallási élet regionális vizsgálata}

A két terület összehasonlító vizsgálatánál fontos körülmény volt a felekezeti hovatartozás tisztázása (4. táblázat). Nem jelzi ugyan az aktív vallásgyakorlást, és fóleg nem a vallásos meggyớzódést, de pusztán a közösséghez tartozás formális tudata, érzése is fontos mozzanatnak túnik és (valószínúleg tudattalanul) eltérő magatartást inkorporál az adott felekezethez tartozóknál. Bizonyítani látszik ezt az a tény is, hogy pl. az öngyilkos magatartásban komoly különbség mutatkozik az egyes felekezethez tartozók körében, függetlenül az aktív vallásgyakorlástól, vallásosságtól. 
4. táblázat. A vizsgált népesség felekezeti megoszlása

\begin{tabular}{lrrrrrr}
\hline Felekezet & \multicolumn{2}{c}{ Bács-Kiskun megye } & \multicolumn{2}{c}{ Vas megye } & \multicolumn{2}{c}{ Összesen } \\
\hline Katolikus & 668 & $66,9 \%$ & 847 & $84,8 \%$ & 1515 & $75,9 \%$ \\
Református & 176 & $17,6 \%$ & 9 & $0,9 \%$ & 185 & $9,3 \%$ \\
Evangélikus & 107 & $10,7 \%$ & 124 & $12,4 \%$ & 231 & $11,6 \%$ \\
Egyéb & 15 & $1,5 \%$ & 3 & $0,3 \%$ & 18 & $0,9 \%$ \\
Nincs megkeresztelve & 27 & $2,7 \%$ & 14 & $1,4 \%$ & 41 & $2,1 \%$ \\
Nem tudja & 5 & $0,5 \%$ & 2 & $0,2 \%$ & 7 & $0,4 \%$ \\
\hline Összesen & 998 & $100,0 \%$ & 999 & $100,0 \%$ & 1997 & $100,0 \%$ \\
\hline
\end{tabular}

1. Mindkét területen a katolikus vallás a meghatározó, de szignifikánsan több a katolikus a dunántúli populációban (66,9\% vs $84,8 \%)$. Nagyjából azonos az evangélikusok aránya, Bácsban a református vallásúak aránya relatíve magas, Vas megyében alig van református. Fontos kiemelni, hogy az alföldi minta $28,3 \%$-a, a vasi minta $13,3 \%$-a protestáns, ami több, mint kétszeres különbséget jelent. Ugyancsak közel kétszerannyi megkérdezettet nem kereszteltek meg az alföldi területen (2,7 \% vs 1,4 \%).

A szakirodalomból ismert, hogy a protestáns népesség körében minden kultúrában magasabb az öngyilkossági hajlam. A több mint kétszeres alföldi protestáns túlsúly is igazolni tudná tehát a két terület között fennálló kétszeres öngyilkossági rátát, de nem szándékunk ezt állítani, éppúgy részmagyarázatnak látjuk, mint ahogyan a depresszív megbetegedések közötti kétszeres különbséget (Zonda és Paksi 2001).

Az öngyilkossági gyakoriságok területi különbségének magyarázatában azonban az alföldi terület igen erôs protestáns túlsúlya (megengedóbb dogmatikájával, mentalitásával) biztosan komoly szerepet játszik.

2. Az egész népességet érintô, az elózô fejezetben használt kérdéseket elemeztük itt is, a két megye azonos adatait összehasonlítva. Az összehasonlító vizsgálatban minden kérdést külön vizsgáltunk, 7 fokú skálát használva. A vallás durkheimi értelemben vett integratív erejét hagyományosan a vallási alkalmakon való részvétel gyakoriságával mértük. E tekintetben az országosan alacsony intenzitás ellenére a két régió viszonylatában várakozásunknak megfeleló irányú szignifikáns különbségek mutatkoztak. A „Milyen gyakran jár misére, istentiszteletre vagy más vallási összejövetelre, alkalomra?" kérdésre a "hetente" vagy "gyakrabban" választ a két területról összesen a megkérdezettek 9,3\%-a adott. A területi eltérés szignifikánsan különbözik: Vasban 10,7\%, míg Bácsban $7,8 \%$ a rendszeres vallásgyakorló (5. táblázat).

A teljes minta 20,1\%-a "aktívan” nem vallásgyakorló, itt szignifikánsan kevesebb a vasi lakos. Az egész minta 27,4\%-a csak alkalomszerúen, 
esetlegesen jár a vallási alkalmakra, ami gyakorlatilag azt jelenti, hogy az egész népesség közel fele (47,5\%) érdemben nem vallásgyakorló. A válaszok együttesen is a vasi népességet mutatják szignifikánsan vallásosabbnak. ${ }^{1}$

A direkt vallásgyakorlás esetleges hiánya nem biztosan jelenti a vallási normák elutasítását, az ilyen értékek negálását, mint ahogy az ellentettje sem jelenti a vallási indíttatású konvenciókhoz való igazodást, ezért a három, ez irányban kutakodó kérdést külön értékeltük az összehasonlító vizsgálatban.

5. táblázat. A „Milyen gyakran jár misére, istentiszteletre?” kérdésre adott válaszok megoszlása megyék szerint

\begin{tabular}{lrrrrrr}
\hline Gyakoriság & \multicolumn{2}{c}{ Bács-Kiskun megye } & \multicolumn{2}{c}{ Vas megye } & \multicolumn{2}{c}{ Összesen } \\
\hline Soha & 230 & $23,0 \%$ & 171 & $17,1 \%$ & 401 & $20,1 \%$ \\
Ritkán & 316 & $31,7 \%$ & 231 & $23,1 \%$ & 547 & $27,4 \%$ \\
Ünnepkor & 285 & $28,6 \%$ & 343 & $34,4 \%$ & 628 & $31,5 \%$ \\
Havonta & 89 & $8,9 \%$ & 146 & $14,6 \%$ & 235 & $11,8 \%$ \\
Hetente & 68 & $6,8 \%$ & 94 & $9,4 \%$ & 162 & $8,1 \%$ \\
Gyakrabban & 10 & $1,0 \%$ & 13 & $1,3 \%$ & 23 & $1,2 \%$ \\
\hline Összesen & 998 & $100,0 \%$ & 998 & $100,0 \%$ & 1996 & $100,0 \%$ \\
\hline
\end{tabular}

A „Függetlenül attól, hogy szokott-e templomba járni, mennyire tartja magát vallásosnak?" kérdésre is hétfokú skálán lehetett válaszolni. A skála középértékénél (4-esnél) kisebb válaszok - egyre fokozódó - elutasítást, az annál nagyobbak pedig - emelkedô - elfogadottságot jeleznek. A skálapontértékek összesítése alapján nem tartja magát vallásosnak Bácsban $48 \%$, Vasban 34,1\%, míg a magukat vallásosnak tartók aránya: Bácsban $29,5 \%$, Vasban $39,2 \%(p<0,001)$.

A „Vallásos hitem nagymértékben befolyásolja mindennapi életemet” kijelentéssel való egyetértést vagy elutasítást is hétfokozatú skálán lehetett jelölni. A két terület között ismét szignifikáns különbség mutatkozott: Bács-Kiskunban 16,5\%, Vas megyében 22,4\% válaszolta azt, hogy hite meglehetősen, illetve nagyon befolyásolja életét $(\mathrm{p}<0,001)$.

\footnotetext{
${ }^{1}$ Nem kétséges, hogy a vallásgyakorlás hiánya nem jelent az esetek egy jó részében aktív ateizmust vagy valami hasonló állapotot. Hogy a megkereszteltetés, és ilyetén formában valamelyik egyházhoz való elvi tartozás önmagában is jelentőséggel bír, arra idéznénk egy - mondhatni - tipikus „nem” választ: „Hát nem járok templomba, kint vagyok a tanyán, nem vagyok vallásos, de azért már mégiscsak Isten áldjon-t köszönünk, este lefekvéskor meg csak Jézust emlegetem."
} 
6. táblázat. A vallásosság mértékét kifejező kérdésre hétfokozatú skálán adott válaszok megoszlása megyei bontásban

Függetlenül attól, hogy szokott-e templomba járni, mennyire tartja magát vallásosnak?

\begin{tabular}{lrrrrrr}
\hline & \multicolumn{2}{c}{ Bács-Kiskun megye } & \multicolumn{2}{c}{ Vas megye } & \multicolumn{2}{c}{ Összesen } \\
\hline Nem & 167 & $16,7 \%$ & 98 & $9,8 \%$ & 265 & $13,3 \%$ \\
2 & 124 & $12,4 \%$ & 91 & $9,1 \%$ & 215 & $10,8 \%$ \\
3 & 193 & $19,3 \%$ & 152 & $15,2 \%$ & 345 & $17,3 \%$ \\
4 & 216 & $21,6 \%$ & 262 & $26,3 \%$ & 478 & $24,0 \%$ \\
5 & 182 & $18,2 \%$ & 216 & $21,7 \%$ & 398 & $19,9 \%$ \\
6 & 62 & $6,2 \%$ & 91 & $9,1 \%$ & 153 & $7,7 \%$ \\
Nagyon & 51 & $5,1 \%$ & 84 & $8,4 \%$ & 135 & $6,8 \%$ \\
Nem tudja & 3 & $0,3 \%$ & 3 & $0,3 \%$ & 6 & $0,6 \%$ \\
\hline Összesen & 998 & $100,0 \%$ & 997 & $100,0 \%$ & 1995 & $100,0 \%$ \\
\hline
\end{tabular}

„Vallásos hitem nagymértékben befolyásolja mindennapi életemet"

\begin{tabular}{lrrrrrr}
\hline & \multicolumn{2}{c}{ Bács-Kiskun megye } & \multicolumn{2}{c}{ Vas megye } & \multicolumn{2}{c}{ Összesen } \\
\hline Nem & 407 & $40,7 \%$ & 374 & $37,5 \%$ & 781 & $39,1 \%$ \\
2 & 152 & $15,2 \%$ & 131 & $13,1 \%$ & 283 & $14,2 \%$ \\
3 & 174 & $17,4 \%$ & 138 & $13,8 \%$ & 312 & $15,6 \%$ \\
4 & 101 & $10,1 \%$ & 130 & $13,0 \%$ & 231 & $11,6 \%$ \\
5 & 91 & $9,1 \%$ & 116 & $11,6 \%$ & 207 & $10,4 \%$ \\
6 & 37 & $3,7 \%$ & 37 & $3,7 \%$ & 74 & $3,7 \%$ \\
Teljesen & 37 & $3,7 \%$ & 71 & $7,1 \%$ & 108 & $5,4 \%$ \\
Nem tudja & - & - & 1 & $0,1 \%$ & 1 & $0,1 \%$ \\
\hline Összesen & 999 & $100,0 \%$ & 998 & $100,0 \%$ & 1997 & $100,0 \%$ \\
\hline
\end{tabular}

"Vallásos hitem nagymértékben befolyásolja, hogy miképpen hozok meg fontos döntéseket"

\begin{tabular}{lrrrrrr}
\hline & \multicolumn{2}{c}{ Bács-Kiskun megye } & \multicolumn{2}{c}{ Vas megye } & \multicolumn{2}{c}{ Összesen } \\
\hline Nem & 457 & $45,7 \%$ & 425 & $42,6 \%$ & 882 & $44,2 \%$ \\
2 & 146 & $14,6 \%$ & 139 & $13,9 \%$ & 285 & $14,3 \%$ \\
3 & 145 & $14,5 \%$ & 115 & $11,5 \%$ & 260 & $13,0 \%$ \\
4 & 88 & $8,8 \%$ & 122 & $12,2 \%$ & 210 & $10,5 \%$ \\
5 & 75 & $7,5 \%$ & 99 & $9,9 \%$ & 174 & $8,7 \%$ \\
6 & 37 & $3,7 \%$ & 33 & $3,3 \%$ & 70 & $3,5 \%$ \\
Teljesen & 51 & $5,1 \%$ & 63 & $6,3 \%$ & 114 & $5,7 \%$ \\
Nem tudja & - & - & 1 & $0,1 \%$ & 1 & $0,1 \%$ \\
\hline Összesen & 999 & $100,0 \%$ & 997 & $100,0 \%$ & 1996 & $100,0 \%$ \\
\hline
\end{tabular}


A „Vallásos hitem nagymértékben befolyásolja, hogy miképpen hozok meg fontos döntéseket" állításra hétfokozatú skálán adott válaszok alapján ismét a vasi minta bizonyult vallásosabbnak (Bács-Kiskun: 16,3\%, Vas: 19,5; p< 0,01) (6. táblázat).

\section{KÖVETKEZTETÉSEK}

Vizsgálatunk a vallásosság látszólag különbözó aspektusairól szól egy olyan országban, ahol a vallási élet, légkör "hagyományosan” igen lanyha. Az egész, 2000 fót számláló, reprezentatív mintából a vallási indikátorok alapján a "nagyon vallásos" és az ",ateista” csoportot leválasztva azt találtuk, hogy a depressziós megbetegedést, az öngyilkossági kísérletek számát tekintve nem észlelhetố különbség a két csoport között. Ugyanakkor markánsan kirajzolódik a vallásos népesség jóval kifejezettebb egészségmegórző, az élet értékét magasabbra helyező attitúdje, és az ennek érdekében tett egészségmagatartás. A társadalom egészségének javítása ügyében tehát fontos hangsúlyozni az egyházak kiemelten fontos szerepét.

A regionális vizsgálatból megállapítható, hogy a két vizsgált régió (Alföld és Dunántúl) felekezeti eloszlása, vallásossága, ebból adódó értékrendje, értékpreferenciája markánsan különbözik. E jelenségek, az ezekból következó magatartások, minták, tradíciók egyértelmúen a kultúra részei. Tehát a két területen a társas létezés terén jelentkezô más magatartások kulturális beágyazottsága nem vitatható, $\mathrm{s}$ a vallási élet fentebb részletezett különbségei feltétlenül figyelembe veendôk a területi különbségek magyarázatában. A prevencióban a jövőben fokozottabban számításba kell mindezt venni, ismételten is hangsúlyozva az egyházak minél aktívabb részvételének fontosságát.

\section{Irodalom}

Andorka R., Vavró I., Cseh-Szombathy L. (1968): Társadalmi elítélés alá esó magatartások elófordulásának területi különbségei. Statisztikai Szemle, 1: 43-54.

Culliford, L. (2002): Spirituality and clinical care. Br. Med. J., 325: 1434-1435.

Cseri P. (2004): A vallásosság és az egészség kapcsolata. Embertárs, 1: 4-11.

Durkheim, E. (1982): Az öngyilkosság. Közgazdasági és Jogi Kiadó, Budapest.

Fabrega, H. (2002): Culture, spirituality and psychiatry. WPA online. http:/ / www.wpanet. org/sectorial/forums.html

Farkas L., Donáth A., Gerevich J. (2005): A vallásosság pszichiátriai vonatkozásai. Psychiatria Hungarica, 20 (3): 178-194. 
Koenig, H. G., McCullough, M. C., Larson, D. B. (2001): Handbook of Religion and Health. Oxford Univ. Press, Oxford.

Koenig, H. G., Pargament, K. I., Nielsen, J. (1998): Religious coping and health status in medically hospitalized older adults. J. of Nervous and Mental Disease, 186: 521-531.

Kopp M., Skrabski Á. (1995): Magyar lelkiállapot. Végeken Kiadó, Budapest.

Kopp M., Skrabski Á. (2000): Magyar lelkiállapot az ezredfordulón. Távlatok, 4: 499-513.

Kopp M., Székely A., Skrabski Á. (2004): Vallásosság és egészség az átalakuló társadalomban. Mentálhigiéné és Pszichoszomatika, 2: 103-125.

Maltby, J., Day, I., Lewis, C. (1999): Pray more and feel better. Br. J. of Health Psychol., 4: 363-378.

Manson, S. M. (1996): Culture and major depression. Current challenges in the diagnosis of mood disorders. Psych. Clin. North Am., 18: 487-501.

Pargament, K. I. (1997): The Psychology of Religion and Coping: Theory, Research and Practice. Guilford Press, New York - London.

Powel, L. H., Shahabi, L., Thoresen, C. E. ( 2003): Religion and spirituality: linkages to physical health. Amer. J. of Psychology, 58: 36-52.

Sloan, R. P., Begiella, E., Powell T. (1999): Religion, spirituality and medicine. Lancet, 353: 664-667.

Sorri, H., Henriksson, M., Lönqvist, J. (1996): Religiosity and suicide. Findings from a national wide psychological autopsy study. Crisis, 17 (3): 123-127.

Towsend, M., Klader, V., Ayele, H., Mulligan, T. (2002): Systematic review of clinical trials examining the effects of religion on health. South. Med. J., 95 (12): 1429-1434.

Zonda T., Paksi B. (2001): Az alföldi-dunántúli népesség mentális állapotának komparatív vizsgálata interdiszciplináris megközelítéssel. Kutatási Beszámoló. Egészségfejlesztési Kutató Intézet és az Oktatási Minisztérium Felsőoktatási Kutatásfinanszírozási Pályázata.

\section{ZONDA, TAMÁS - PAKSI, BORBÁLA \\ PROTECTIVE EFFECT OF RELIGIOSITY ON THE SOMATIC AND/OR MENTAL HEALTH}

Authors studied the representative samples of two Hungarian counties with traditionally low and high suicide rates. They picked out the questions related to the religious life and studied the connection between the (outside and inside) religiosity and health-behavior. Among religious people a much higher degree of value of life was found and a more intensive drive to keep it: the alcohol consumption, smoking, the suicide intention and attitude were significantly lower. Much more religious people have turned to cancer-screening and to psychologists. The religiosity had no significant effect on the morbidity of major depression and suicide attempts. In the county of low suicide rate there are twice as many catholic people, religiosity and faith play a much more intensive role in every-day life. The findings must be important in the prevention of the somatic and mental health as well.

Keywords: religiosity, health behavior, suicide, major depression 